\title{
EFEKTIVITAS UNDANG-UNDANG NOMOR 33 TAHUN 2014 TENTANG JAMINAN PRODUK HALAL DALAM PERLINDUNGAN KONSUMEN
}

\author{
Fajaruddin \\ Fakultas Hukum Universitas Muhammadiyah Sumatera Utara \\ Jl. Kapt. Mukhtar Basri Nomor 3, Medan - Sumatera Utara \\ Email: fajaruddin@umsu.ac.id
}

\begin{abstract}
Abstrak
Undang-Undang Nomor 8 Tahun 1999 tentang Perlindungan Konsumen memberikan perlindungan untuk hak-hak konsumen. Di antara perlindungan ini adalah perlunya label halal pada setiap produk makanan dan minuman. Pelanggaran label halal adalah kesalahan yang dilakukan oleh bisnis terhadap dimasukkannya label halal dalam penerbitan produk dan layanan. Bahkan masih banyak produk makanan dan minuman yang menggunakan bahan-bahan tidak sah, atau dengan kata lain masih banyak produk makanan dan minuman yang masih dalam krisis akibat halal. Undang-Undang 33 Tahun 2014 tentang Jaminan Produk Halal adalah penyempurnaan hukum yang sebelumnya mengatur perlunya peleburan halal. Undang-undang ini diharapkan menjadi aturan yang lebih sempurna dalam melindungi konsumen dari produk terlarang.
\end{abstract}

\section{Kata Kunci: Efektivitas, Jaminan, Produk, Halal, Konsumen}

\section{Abstract}

Law No. 8 of 1999 concerning Consumer Protection provides protection for consumer rights. Among these protections is the necessity of halal labels on every food and beverage product. Violation of halal labeling is a mistake made by businesses against the inclusion of halal labels in the publishing of products and services. In fact there are still many food and beverage products that use illegitimate ingredients, or in other words there are still many food and beverage products that are still in crisis from halal. The Law No. 33 of 2014 Concerning Halal Product Guarantee Law is a refinement of the law which previously regulated the necessity for halal smelting. This law is expected to be a more perfect rule in protecting consumers from illicit products.

Keywords: Effectiveness, Guarantees, Product, Halal, Consument

\section{PENDAHULUAN}

Sebelum berlakunya Undang-Undang Nomor 33 Tahun 2014 tentang jaminan produk halal, ternyata telah ada beberapa undang-undang yang mengatur tentang produk halal yaitu; Undang-undang Nomor 7 tahun 1996 Tentang pangan, Undang-Undang Nomor 8 Tahun 1999 Tentang Perlindungan Konsumen, Undang-Undang Nomor 18 tahun 2012 tentang Pangan.

Undang-Undang Nomor 7 Tahun 1996 tentang Pangan pasal 30 ayat 2 huruf e menyebutkan:

(2) Label, sebagaimana dimaksud pada ayat 1 memuat sekurang-kurangnya keterangan mengenai : 
Jurnal Ilmu Hukum

FAKULTAS HUKUM UMSU
Efektivitas Undang-Undang...(Fajaruddin)

Volume 3 Nomor 2, Juli-Desember 2018, 204-216 DOI: https://doi.org/10.30596/dll.v3i2.3151

1. nama produk

2. daftar bahan yang digunakan

3. berat bersih atau isi bersih

4. nama dan alamat pihak yang memperoduksi atau memasukkan pangan ke dalam wilayah Indonesia.

5. keterangan tentang halal.

6. tanggal, bulan dan tahun kadaluarsa.

Kemudian pada Undang-Undang Nomor 18 tahun 2012 mempertegas dan memperbanyak ketentuan yag mengatur tentang pangan halal maupun dalam ketentuan yang menyatakan 'tidak bertentangan dengan agama'. Perlindungan bagi konsumen sudah tampak pada Undang-Undang Nomor 7 Tahun 1996 tentang Pangan dan dilanjutkan oleh UndangUndang Nomor 18 Tahun 2012 tentang Pangan yang menunjukkan secara politik hukum pemerintah memberikan perlindungan kepada masyarakat mengonsumsi pangan yang halal.

Lalu dalam Undang-Undang Nomor 8 Tahun 1999 Tentang Perlindungan Konsumen bertujuan untuk melindungi konsumen dari produk-produk yang sudah dinyatakan halal dalam bentuk label halal. Kemudian diperkuat dengan lahirnya Undang-Undang Nomor 33 Tahun 2014 tentang Jaminan Produk Halal. Prosedur pengurusan lebel halal telah memiliki peraturan yang dikeluarkan oleh Majelis Ulama Indonesia. Seiring dengan itu sesuai dengan Undang-Undang Nomor 8 Tahun 1999 Tentang Perlindungan Konsumen yang mengharuskan adanya pencantuman lebel halal, Undang-Undang Nomor 33 Tahun 2014 Tentang Jaminan Produk Halal, maka secara khusus makalah ini ingin menelaah ulang apakah efektif pelaksanaan jaminan halal kaitannya dengan perlindungan konsumen.

Undang-Undang No 8 Tahun 1999 Tentang Perlindungan Konsumen memberikan perlindungan hak-hak konsumen. Diantara perlindungan tersebut adalah adanya keharusan lebel halal pada setiap produk makanan maupun minuman. Pelanggaran lebelisasi halal adalah kesalahan yang dilakukan oleh pelaku usaha terhadap pencantuman lebel halal dalam penerbitan suatu produk dan jasa. Bahkan terindikasi masih banyak produk makanan dan minuman yang menggunakan bahan haram, atau dengan kata lain masih banyak produk makanan dan minuman yang masih krisis dari halal.

Pada sisi lain sebenarnya LPPPOM Majelis Ulama telah membuat sejumlah aturan berupa prosedur bagi perusahaan yang ingin memperoleh sertifikat halal LPPOM MUI. Hal ini untuk memudahkan pelaku usaha untuk mendapat sertifikat halal. Adapun pelaku usaha atau perusahaan yang ingin memperoleh sertifikat halal tersebut, baik industri makanan dan minuman.

Namun dalam kenyataan ada saja masih beberapa produk makanan dan minuman yang tidak memiliki label halal. Sepertinya walaupun sudah ada undang-undang perlindungan konsumen ternyata masih ada ditemukan produk yang tidak ada lebel halal diperjualbelikan. Undang-Undang Jaminan Produk Halal telah disahkan tahun 2014, dalam rangka untuk lebih terjaminnya produk makanan maupun minuman yang dikonsumsi oleh umat Islam. Namun apakah Undang-Undang tersebut telah efektif sebagai perlindungan bagi konsumen.Maka ini 
Jurnal Ilmu Hukum

FAKULTAS HUKUM UMSU
Efektivitas Undang-Undang...(Fajaruddin)

Volume 3 Nomor 2, Juli-Desember 2018, 204-216

DOI: https://doi.org/10.30596/dll.v3i2.3151

yang akan disampaikan dalam makalah ini. melalui analisis efektifitas jaminan produk halal terhadap perlindungan konsumen.

\section{METODE PENELITIAN}

Penelitian hukum adalah seluruh upaya untuk mencari dan menemukan jawaban yang benar (right answer) dan/atau jawaban yang tidak sekali-kali keliru (true answer) mengenai suatu permasalahan, untuk menjawab segala macam permasalahan hukum diperlukan hasil penelitian yang cermat dan sahih untuk menjelaskan dan menjawab permasalahan yang ada (Zainudin Ali, 2011, h. 18).

Jenis penelitian yang digunakan adalah penelitian hukum normatif (normative law research), yaitu penelitian hukum yang mengkaji hukum tertulis dari berbagai aspek, yaitu aspek teori, sejarah, filosofi, perbandingan, struktur dan komposisi, lingkup dan materi, konsistensi, penjelasan umum pasal demi pasal, formalitas dan kekuatan mengikat suatu undang-undang, serta bahasa hukum yang digunakan, tetapi tidak mengkaji aspek terapan atau implementasinya (Abdulkadir Muhammad, 2004, h. 120). Penelitian ini dilakukan untuk mengkaji perlindungan hukum konsumen bagi umat muslim yang ada di Indonesia terkait dengan jaminan produk halal.

\section{PEMBAHASAN \\ Pengertian Efektivitas}

Peraturan perundang-udangan baik yang tingkatnya lebih rendah maupun yang lebih tinggi bertujuan agar masyarakat maupun aparatur penagak hukum dapat melaksanakannya secara konsisten dan tanpa membedakan antara masyarakat yang satu dengan yang lainnya. Semua orang dipandang sama di hadapan hukum (equality before the law). Namun peraturan perundangan tersebut sering dilanggar, sehingga aturan tidak efektif. Bisa jadi ketidakefektivan sebuah undang-undang disebabkan: Karena Undangundang-nya kabur atau tidak jelas, 2. Aparat yang tidak konsisten, 3. Aparat dan atau masyarakat tidak mendukung pelaksanaan undang-undang tersebut. Apabila undangundang tersebut dilaksanakan dengan baik, maka undang-undang itu dikatakan efektif. Dikatakan efektif karena bunyi undang-undangnya jelas dan tidak perlu adanya penafsiran, aparatnya menegakkan hukum secara konsisten dan masyarakat yang terkena aturan sangat mendukungnya. Maka teori yang menganalisis tentang hal ini disebut teori efektivitas hukum Salim HS dan Erlies Septiana Nurbani, 2017, h. 301).

Istilah teori efektivitas hukum berasal dari terjemahan bahasa Inggris, yaitu effektiveness of the legal theory, bahasa Belanda disebut dengan effectiviteit van de juridische theorie, bahasa Jermannya, yaitu wirksamkeitt der rechtlichen theorie. Salim HS dan Erlies Septiana Nurbani, Penerapam Teori Hukum Pada Penelitian Tesis dan Disertasi, (Salim HS \& Erlies Septiana Nurbani, 2017, h. 301). Hens Kelsen memberikkan defenisi tentang efektivitas hukum adalah:

Apakah orang-orang pada kenyataannya berbuat menurut suatu cara untuk 
Jurnal Ilmu Hukum

FAKULTAS HUKUM UMSU
Efektivitas Undang-Undang...(Fajaruddin)

Volume 3 Nomor 2, Juli-Desember 2018, 204-216

DOI: https://doi.org/10.30596/dll.v3i2.3151

mengindari sanksi yang diancamkan oleh norma hukum atau bukan, dan apakah sanksi tersebut benar-benar dilaksanakan bila syaratnya terpenuhi atau tidak terpenuhi.

Konsep efektivitas dalam defenisi yang dikemukakan oleh Hens Kalsen difokuskan pada subjek dan sanksi. Subjek yang melaksanakannya, yaitu orang-orang atau badan hukum. Orang-orang tersebut harus melaksanakan hukum sesuai dengan bunyinya norma hukum. Bagi orang-orang yang dikenai sanksi hukum, maka sanksi hukum benar-benar dilaksanakan atau tidak.

Anthony Allot mengemukakan tentang efektivitas hukum adalah:

Hukum akan menjadi efektif jika tujuan keberadaan dan penerapannya dapat mencegah perbuatan-perbuatan yang tidak diinginkan dapat menghilangkan kekacauan. Hukum yang efektif secara umum dapat membuat apa yang dirancang dapat diwujudkan. Jika suatu kegagalan, maka kemungkinan terjadi pembetulan secara gampang jika terjadi keharusan untuk melaksanakan atau menerapkan hukum dalam suasana baru yang berbeda, hukum akan sanggup menyelesaikannya (Salim HS dan Erlies Septiana Nurbani, 2017, h. 301).

Konsep Anthony Allot tentang efektivitas hukum difokuskan pada perwujudannya. Hukum yang efektif secara umum dapat membuat apa yang dirancang dapat diwujudkan dalam kehidupan sosial kemasyarakatan. Dengan mengungkapkan dan menganalisis kedua pendapat di atas maka teori efektivitas hukum adalah "Teori yang mengkaji dan menganalisis tentang keberhasilan, kegagalan dan faktor-faktor yang mempengaruhi dalam pelaksanaan dan penerapannya."

Ada tiga fokus kajian teori efektivitas hukum, yang meliputi :

a. Keberhasilan dalam pelaksanaan hukum.

b. Kegagalan di dalam pelaksanaannya.

c. Faktor-faktor yang mempengaruhinya (Salim HS dan Erlies Septiana Nurbani, 2017, h. 303).

Keberhasilan di dalam pelaksanaan hukum adalah bahwa hukum yang dibuat itu telah tercapai maksudnya. Maksud dari norma hukum adalah mengatur kepentingan manusia. Apabila norma hukum itu ditaati dan dilaksanakan oleh masyarakat maupun penegak hukum, maka pelaksanaan hukum itu dikatakan efektif atau berhasil di dalam imlementasinya. Hal ini, dapat dilihat di dalam masyarakat yang telah secara sadar mebaikot makanan dan minuman yang tidak mencantumkan label halal.

Kegagalan di dalam pelaksanaan hukum adalah bahwa ketentuan-ketentuan hukum yang telah ditetapkan tidak mencapai maksudnya atau tidak berhasil di dalam implementasinya. Hal ini dapat dicontohkan bahwa setiap produk makanan dan minuman yang diproduksi belum semuanya mencantumkan lebel halal.

Faktor-faktor yang mempengaruhi adalah hal-hal yang ikut menyebabkan atau berpengarih di dalam pelaksanaan dan penerapan hukum tersebut. Faktor-faktor yang mempengaruhi dapat dikaji dari: 
Jurnal Ilmu Hukum FAKULTAS HUKUM UMSU
Efektivitas Undang-Undang...(Fajaruddin)

Volume 3 Nomor 2, Juli-Desember 2018, 204-216 DOI: https://doi.org/10.30596/dll.v3i2.3151

a. Aspek keberhasilannya, dan

b. Aspek kegagalannya.

Faktor-faktor yang mempengaruhi keberhasilan itu, meliputi substansi hukum, struktur, kultur, dan fasilitasnya. Norma huku dikatakan berhasil atau efektif apabila norma itu ditaati dan dilaksanakan masyarakat maupun aparatur penegak hukum itu sendiri. Hal ini, dapat dicontohkan pelaksanaan hukum yang berhasil yaitu pelaku usaha telah mendaftarkan dan mencantumkan label halal pada produk makanan dan minuman yang mereka produksi.

Faktor-faktor yang mempengaruhi kegagalan di dalam pelaksanaan hukum adalah karena norma hukum yang kabur atau tidak jelas, aparatur hukum yang korup, atau masyarakat yang tidak sadar atau taat pada hukum atau fasilitas yang tersedia untuk mendukung pelaksanaan hukum itu sangat minim.

\section{Pangan Haram Dalam Islam}

Salah satu prinsip ajaran Islam yang berhubungan dengan kebendaan adalah bahwa segala macam benda yang diciptakan Allah di alam semesta ini dibolehkan untuk dimanfaatkan bagi kepentingan manusia. Para ulama mendasarkan ketetapan bahwa segala sesuatu itu asalnya mubah, dibolehkan dengan dalil sejumlah ayat-ayat al-Quran. Prinsip yang disebut : الأصل فى الأشياء الاباحة ini menyangkut hubungan kebendaan dengan segala macam bentuk perbuatan manusia yang tidak termasuk urusan ibadah, yakni yang biasa diidtilahkan dengan adat atau muamalah.

Di dalam masalah muamalah,prinsipnya adalah segala sesuatu pada dasarnya tidak haram, tidak terikat, kecuali memang syari' yakni pembuat syariat sendiri (Allah SWT), telah dijelaskan keharamannya, sebagaimana ditegaskan dalam al-Quran surat al-An'am ayat 119 yang artinya:

Mengapa kamu tidak mau memakan (binatang-binatang yang halal) yang disebut nama

Allah ketika menyembelihnya, Padahal Sesungguhnya Allah telah menjelaskan kepada kamu apa yang diharamkan-Nya atasmu, kecuali apa yang terpaksa kamu memakannya. dan Sesungguhnya kebanyakan (dari manusia) benar benar hendak menyesatkan (orang lain) dengan hawa nafsu mereka tanpa pengetahuan. Sesungguhnya Tuhanmu, Dia-lah yang lebih mengetahui orang-orang yang melampaui batas.

Maka dalam urusan muamalah, segala urusan pada dasarnya adalah boleh, tidak satupun yang terlarang kecuali memang telah diharamkan.Urusan makanan-minum, pemilihan pangan, pengelolaan pangan, danlain-lain, manusia tidak diberi penjelasan yang sangat detail seperti dalam urusan ibadah. Petunjuk dan dalil-dalil yang berkenaan dengan urusan muamalah datamg dalam bentuk prinsip atau petunjuk umum.

Hal ini dapat dipahami karena cabang-cabang dari urusan selain ibadah (selain ritus) tidak terhingga banyaknya, senantiasa berubah dan berkembang seiring dengan dunamika perkembangan peradaban manusia. Sebagaimana dinyatakan Abdul Halim Uways, Allah sebagai pembuat hukum (syari') tidak menetapkan hukum secara taken for granted dalam 
segenap hal. Bahkan Allah membiarkan adanya suatu wilayah yang luas tanpa terikat dengan nas. Tujuannya adalah untuk memberikan keleluasaan, kemudahan, dan rahmat bagi makhlukNya (Abdul Halim Uways, 1998, h. 122-133).

Pangan manusia dapat dibedakan atas dua golongan besar, nabati damn hewani yang masing-masing menghimpun sangat banyak jenis dan macam sumber pangan. Ribuan, bahkan jutaan spesies tumbuhan dan hewan yang berada di alam yang telah tersedia sebagai sumber pangan yang dibutuhkan manusia. Untuk mengenali dan membedakan pangan halal dari yang haram, serta mengetahui batas-batasnya yang telah ditetapkan oleh Allah dan RasulNya sebagaimana dinyatakan dalam nas-nas al-Quran dan as-Sunnah, yaitu; (Wawan Junaidi, 2006, h. 61)

a. Pangan yang diharamkan nas al-Quran
1) Bangkai
2) Darah
3) Daging Babi
4) Sembelihan Sesaji
5) Khamar

b. Pangan yang diharamkan as-Sunnah

1) Binatang Buas Bertaring dan Burung Bercengkram

2) Himar Keledai dan Kuda

3) Ular, Burung Gagak, Kelabang dan Tikus

c. Alasan Keharaman

1) Membahayakan

2) Menjijikkan

3) Memabukkan

\section{Jaminan Produk Halal}

Jaminan produk halal menurut Undang-Undang Nomor 8 Tahun 1999 tentang perlindungan konsumen, menyatkan bahwa pelaku usaha dilarang memperoduksi dan/atau memperdagangkan barang dan/atau jasa yang tidak mengikuti ketentuan berproduksi secara halal, sebagaimana pernyataan "halal" yang dicantumkan dalam label (UndangUndang Nomor 8 Tahun 1999 tentang Perlindungan Konsumen (Pasal 8 ayat 1 huruf h). Peraturan perundangan lainnya juga memepertegas pentingnya pencantuman label halal tercantum di dalam Unddang-Undang Nomor 18 Tahun 2012 tentang Pangan, yang pada bab VII tentang Keamanan Pangan, bagian kedelapan yang berjudul Jaminan Produk Halal bagi yang dipersyaratkan (Undang-Undang Nomor 18 Tahun 2012 tentang Pangan Bab VII Bagian Kedelapan), dan menentukan bahwa pemerintah dan Pemerintah Daerah berkewajiban meningkatkan pemenuhan kuantitas dan kualitas konsumsi pangan melalui:

a. Penetapan target pencapaian angka konsumsi pangan per kapita per-tahun sesuai dengan angka kecukupan gizi.

b. Menyediakan pangan yang beragam, bergizi seimbang, aman dan tidak bertentangan dengan agama, keyakinan, dan budaya masyarakat, dan, 
Jurnal Ilmu Hukum

FAKULTAS HUKUM UMSU
Efektivitas Undang-Undang...(Fajaruddin)

Volume 3 Nomor 2, Juli-Desember 2018, 204-216 DOI: https://doi.org/10.30596/dll.v3i2.3151

c. Pengembangan pengetahuan dan kemampuan masyarakat dalam pola konsumsi pangan yang beragam, bergizi seimbang, bermutu dan aman (Pasal 95 UndangUndang Nomor 18 Tahun 2012 tentang Pangan).

Oleh sebab itu sebagai kewajiban pemerintah pusat maupun pemerintah daerah dalam rangka meningkatkan pemebuhan kuantitas dan kualitas konsumsi pangan yang beragan, bergizi seimbang, aman dan tidak bertentangan dengan agama, keyakinan dan budaya dalam undang-undang Nomor 8 Tahun 2012 tentang Pangan, merupakan salah satu ketentuan yang pada frasa 'tidak bertentangan dengan agama dan keyakinan" menjadikan kewajiaban pencantuman label halal dikenakan pada pangan, yang kemudian dalam Undang-Undang Jaminan Produk Halal lebih diperjelas dan dipertegas kewajiban pencantuman label halal (Abdurrahman Konoras, 2017, h.1-2).

Sebelum dimuat dalam Undang-Undang Nomor 8 tahun 1999 Undang-Undang Perlindungan Konsumen dan Undang-Undang Pangan ketentuan yang mewajibkan pencantuman label halal sebenarnya sudah diatur di dalam peraturan yang rendah derajat hukumnya seperti pada keputusan bersama Menteri Kesehatan dan Menteri Agama nomor 427/MENKES/SKB/VIII/1985 dan Nomor 68 Tahun 1985 tentang tulisan 'halal' pada lebel makanan, tertanggal 12 Agustus 1985 yang pada Pasal 2 menyatakan produsen yang mencantumkan tulisam 'halal' pada label/penandaan makanan produknya bertanggung jawab terhadap halalnya makanan tersebut bagi pemeluk agama Islam. Datur pula pada Pasal 3 bahwa produsen sebagaimana dimaksud pada ayat 2 Keputusan Bersama ini berkewajiban menyampaikan laporan kepada Departemen Kesehatan Republik Indonesia dengan mencantumkan keterangan tentang proses pengolahan dan komposisi bahan yang digunakan.

Hadirnya Undang-Undang Jaminan Produk halal pada dasarnya sudah mulai dirintis oleh sejumlah ketentuan sebelumnya, baik dalam derajat dan/atau level yang rendah seperti Keputusan Bersama Menteri Kesehatan dan Menteri Agama, kemudian tercantum pada pasal 8 ayat 1 huruf h Undang-Undang Nomor 8 Tahun 1999 tentang Perlindungan Konsumen, serta dalam sejumlah pasal Undang-Undang Pangan tersebut adalah sejumlah ketentuan peraturan perundangan yang telah mengadopsi salah satu bagian dari prinsip/tujuan syari'ah yang bertujuan memelihara keselamatan agama (hifzu ad-Din), jiwa (hifzu an-Nafs), akal (hifzu al-Aqal), keturunan (hifzu an-Nasab) dan harta benda (hifzu al-Mal). Pencantuman label halal adalah bagian penting sebagai jaminan hukum dan perlindungan hukum bagi masyarakat sekaligus sebagai bentuk kepastian hukum yang memiliki urgensi penting.

Persoalan kehalalan suatu produk adalah suatu hal yang tidak dapat ditawar-tawar karena menyangkut prinsip penting dan mendasar yaitu prinsip syari'ah mengenai berbagai produk makanan, minuman, obat-obatan maupun kosmetika. Kehadiran hukum memberikan perlindungan (to protect) terhadap konsumen sebagaimana diusung oleh substansi Undang-Undang Jaminan Produk Halal sekaligus juga dapat menjamin kepastian hukum, bahwa hubungan hukum antara produsen dan konsumen sama-sama 
Jurnal Ilmu Hukum FAKULTAS HUKUM UMSU
Efektivitas Undang-Undang...(Fajaruddin)

Volume 3 Nomor 2, Juli-Desember 2018, 204-216 DOI: https://doi.org/10.30596/dll.v3i2.3151

diikat dan didasarkan pada aturan hukum yakni dengan penerapan lebelisasi halal pada produk Abdurrahman Konoras, 2017, h. 3).

\section{Perlindungan Konsumen Dalam Islam}

Sebelum Islam datang, Mekkah telah menjadi perhatian kabilah jazirah Arab, hal ini karena perhatian tertuju kepada Ka'bah dan suku Quraisy yang juga tinggal dan berdomisili di Mekkah. Suku Quraisy merupakan penjaga Ka'bah yang merupaka tempat suci bagi bangsa Arab. Suku Quraisy telah mendapatkan keuntungan yang sangat besar atas status mereka sebagai pemelihara Ka'bah, begitu juga dalam perdagangan. Perdagangan bagi suku Quraisy dan bangsa Arab umumnya merupakan fakta yang terjadi sebagai akibat dari tandus dan gersangnya wilayah Arab, sehingga sektor prtanian bukan menjadi pilihan utama bagi bangsa Arab (Jusmaliani, 2008, h. 47).

Keuntungan suku Quraisy tersebut dipetik dalam skala yang lebih besar, yakni terjalinnya hubungan politik ekonomi dan perdagangan yang lebih luas. Hal ini buktikan denga terbitnya perizinan perjalanan dan jaminan keamanan berdagang (aylaf) bagi suku Quraisy dari penguasa negara-negara tetangga, pada waktu itu adalah Iraq, Syiria, Yaman, dan Etiopia (Afzalul Rahman, 2000, h. 8). Karena itu pula, Mekkah dianggap sebagai ibu kota seluruh Jazirah Arab, dan juga dipandang sebagai pusat perdagangan Jazirah Arab (Muhammad Husein Haekal, 1984, h. 33).

Keberhasilan bangsa Quraisy dalam perdagangan bukan tanpa alasan, dalam The Wealth of Nations, Adam Smith menceritakan bahwa ketika para pedagang muslim akan memasuki suatu kota untuk berjualan, mereka akan mengundang orang-orang yang lewat, termasuk orang miskin, untuk makan bersama. Mereka makan bersama dan bersila, memulai makan dengan ucapan Bismillah dan mengakhirinya dengan alhamdulillah. Demikianlah kiat para pedagang muslim memelihara kepentingan bisnisnya, yakni dengan bermurah hati dan sambutan yang hangat (Afzalul Rahman, 2000, h. 13).

Secara historis, bahwa sejarah perlindungan konsumen dalam Islam telah dimulai dari masa Muhammad sebelum diangkat menjadi Rasulullah, beliau membawa dagangan Khadijah binti Khuwailid dengan mendapat upah. Walaupun tidak banyak ditemukan tentang perlindungan konsumen dari praktek perdagangan yang dilakukan oleh Rasulullah SAW, namun dapat ditemukan prinsip-prinsip perlindungan konsumen dari praktek perdagangan yang beliau lakukan. Kejujuran, keadilan, dan integritas Rasulullah SAW. tidak diragukan oleh penduduk Mekkah, sehingga potensi tersebut meningkatkan reputasi dan kemampuannya dalam memperdagangkan barang dagangan Khadijah. Karena kejujuran dan prestasinya tersebut, Rasulullah berhasil menjual barang dagangan Khadijah dengan mendapat keuntungan yang lebih banyak dibandingkan dengan orang lain.

Setelah Muhammad diangkat menjadi Rasulullah, konsumen juga menndapat perhatian dalam ajaran Islam, baik dalam al-Quran maupun dalam hadis. Perdagangan yang adil dan jujur menurut al-Quran adalah perdagangan yang tidak menzalimi dan tidak pula dizalimi. Sebagaimana tercantum dalam al-Quran surat al-Baqarah ayat 279 yang 
Efektivitas Undang-Undang...(Fajaruddin) DOI: https://doi.org/10.30596/dll.v3i2.3151

artinya "Maka bagimu pokok hartamu; kamu tidak Menganiaya dan tidak (pula) dianiaya".

Sekilas ayat di atas sepertinya tidak ada kaitannya dengan perlindungan konsumen namun jika dicermati potongan ayat tersebut mengkisahkan tentang persolan harta tidak boleh saling menzolimi atau menganiaya antara pelaku usaha dan konsumen. Maksudnya penganiayaan hak-hak konsumen maupun hak-hak produsen (Zulham, 2013, h. 41).

Rasulullah mencontohkan bahwa perdagangan dalam Islam haruslah dilandasi dengan etika dan nilai-nilai yang menjunjung tinggi kejujuran dan keadilan bisnis. Rasulullah berdagang secara adil, jujur dan meletakkan dasar-dasar mekanisme pasar, termasuk dalam hal transaksi perdagangan kedua belah pihak dapat saling menjual dan membeli barang secara ikhlas (an tarodhin), tanpa ada campur tangan, intervensi dan paksaan dalam harga.

Jika pasar dalam keadaan tidak sehat, di mana terjadi penipuan, penimbunan, atau perusakan pasokan dengan tujuan menaikkan harga yang berujung pada kerugian konsumen. Maka menrut Ibnu Taimiyah pemerintah wajib melakukan regulasi harga pada tingkat yang adil antara produsen dan konsumen tanpa ada pihak yang dirugikan atau dieksploitasi oleh pihak lain (Ikhwan Hamdani, 2003, h. 28).

Setelah Rasulullah hijrah ke Madinah, berbagai prinsip ekonomi yang tidak adil dan mengarah kepada zholim telah dihapus serta dilarang melakukannya. Seperti penahanan stok, spekulasi, pembatalan informasi penting tentang produk, penjualan dengan sumpah palsu, atau informasi menyesatkan. Praktik-praktik pedagangan yang dilarang Rasulullah SAW diantaranya: (Pelarangan ini terdapat dalam surat al-Muthaffifin: 1-6).

a. Talaqqi Rukban yaitu mencegat pedagang yang membawa barang dari tempat produksi sebelum sampai ke pasar. Rasulullah melarang tindakan ini agar dapat menghindari ketidaktahuan konsumen atau produsen tentang harga barang.

b. Gisyah yaitu menyembunyikan cacat barang yang dijual, bisa juga dengan mencampurkan produk cacat ke dalam barang yang berkualitas tinggi, sehingga konsumen akan mengalami kesulitan untuk mengetahui secara tepat kualitasbarang yang diperdagangkan, dengan demikian penjual akan mendapatkan harga yang tinggi untuk barang yang cacat atau kualitas buruk.

c. Perdagangan Najasy yaitu praktik perdagangan di mana seseorang berpura-pura sebagai pembeli yang menawar tinggi harga barang disertai pujian kualitas secara tidak wajar, dengan tujuan untuk menaikkan harga barang.

d. Produk haram yaitu memperdagangkan barang-barang yang telah dilarang dan diharamkan oleh al-Quran dan as-Sunnah (Pelarangan ini terdapat dalam QS. alBaqarah: 173, al-Maidah: 3, al-An'am: 145, an-Nahal: 115). Hal ini tentunya membahayakan bagi konsumen baik secara jasmaniah maupun rohaniah.

e. Riba yaitu pengambilan tambahan dalam transaksi jual beli maupun simpan pinjam yang berlangsung secara zholim dan bertentangan dengan prinsip muamalat secara islami. (Pelarangan ini terdapat dalam surat al-Baqarah: 275, 276, 278, 279, Ali Imran: 130, ar-Rum: 39)

f. Tathfif, ialah tindakan yang mengurangi timbangan atau takaran barang yang akan dijual, tentu saja praktik dagang seperti ini sangat merugikan konsumen. 
Jurnal Ilmu Hukum

FAKULTAS HUKUM UMSU
Efektivitas Undang-Undang...(Fajaruddin)

Volume 3 Nomor 2, Juli-Desember 2018, 204-216 DOI: https://doi.org/10.30596/dll.v3i2.3151

Praktik perdagangan yang disebutkan di atas tampak bahwa dalam Islam Rasulullah mengajarkan adanya nilai-nilai perlindungan hak-hak konsumen. Walaupun pada saat itu termonologi "konsumen" belum dikenal seperti saat ini. Bahkan sebelum Barat dan dunia modern mengatur perlindungan konsumen, Islam telah meletakkan prinsip-prinsip dasar perlindungan konsumen. Namun perlindungan konsumen yang diajarkan oleh Rasulullah belum terinci seperti sekarang ini.

\section{Efektifitas Jaminan Produk Halal Sebagai Perlindungan Konsumen}

Lahirnya Undang-Undang Jaminan Produk Halal tentunya mema,bah kuatnya perlindungan konsumen terutama bagi orang Islam. Hal ini nampak dari fenomena bangkitnya kesadaran umat Islam dalam mengkonsumsi berbagai produk halal yang diperdagangkan. Walaupun hal ini sebenarnya sudah mulai dirintis di dalam bentuk ketentuan hukum yang rendah seperti Peraturan Bersama Menteri Kesehatan dan Menteri Agama Nomor 427/MenKes/SKB/VIII/1985 dan Menteri Agama Nomor 68 Tahun 1985 tentang Pencantuman Tulisan 'halal' pada lebel makanan yang ditetapkan pada tanggal 12 Agustus 1985 yang pada Pasal 2 menyatakan bahwa produsen yang mencantumkan tulisan 'halal' pada lebel/penandaan makanan produknya bertanggungjawab terhadap halalnya makanan tersebut bagi pemeluk agama Islam.

Keputusan bersama Menteri tersebut selanjutnya menjadi bagian yang diadopsi dalam Undang-Undang Nomor 7 Tahun 1996 tentang Pangan sebagai peraturan perundangan yang menentukan kewajiban mencantumkan lebel mengenai keterangan halalsebagai bagian dari ketentuan lebel dan iklan pangan. Undang-Undang Nomor 7 Tahun 1996 tentang Pangan bersama dengan Undang-Undang Nomor 8 Tahun 1999 tentang Perlindungan Konsumen merupakan peraturan perundangan-undangan yang mempelopori ketentuan produk jaminan halal, yang selanjutnya Undang-Undang Nomor 7 Tahun 1996 tentang Pangan diganti dengan UUP 2012 lebih jelas dan tegas mengatur tentang Jaminan Produk Halal bagi yang dipersyaratkan.

Selanjutnya peraturan perundangan tersebut disempurnakan dengan diudangkannya Undang-Undang Nomor 33 Tahun 2014 tentang Jaminan Halal yang merupakan peraturan perundangan yag lebih komprehensif dan integral yang secara khusus mengatur tentang jaminan produk halal di Indonesia sebagai konsekwensinya dalam prinsip hukum dikenal prinsip "Lex posterior derogate legi periori", bahwa aturan yang baru mengesamapingkan aturan hukum yang lama.

Undang-undang Nomor 33 Tahun 2014 tentang Jaminan Halal mengatur keseluruhan aspek baik dari proses, prosedural, kelembagaan maupun pertanggungjawaban pidananya. Jaminan Produk Halal sebagai perlindungan bagi konsumen muslim dalam penerapannya di Indonesia, adalah sebagai dari perkembangan dalam penerapan sertifikasi produk halal yang tidak terpisahkan dari bangkitnya kesadaran pemeluk agama Islam terhadap pentingnya mengonsumsi produk-produk halal yang kecendrungannya belum secara tegas ditanggapi oleh pemerintah dan pelaku usaha sebagai faktor penting dalam pengembangan 
Jurnal Ilmu Hukum FAKULTAS HUKUM UMSU
Efektivitas Undang-Undang...(Fajaruddin)

Volume 3 Nomor 2, Juli-Desember 2018, 204-216 DOI: https://doi.org/10.30596/dll.v3i2.3151

bisnis baik secara nasional maupun internasional.

Kehadiran Undang-Undang Nomor 33 Tahun 2014 tentang Jaminan Halal, selayaknya akan lebih menjamin perlindungan konsumen terutama terhadap produk makanan dan minuman yang dikemas. Hal ini disebutkan bahwa dalam pengajuan permohonan Sertifikasi Halal harus dilengkapi dengan:

a. Para pelaku usaha

b. Nama dan jenis produk

c. Daftar produk dan bahan yang digunakan, dan

d. Proses pengolahan produk.

Penerapan Jaminan Produk Halal menjadi sebuah pembelajaran bagi para produsen untuk mengefektikan pencantuman lebel halal atas amanah Undang-Undang tersebut. Karena hal ini dapat dijadikan sebagai persaingan untuk merebut pangsa pasar ekspor komoditas. Prospek ekspor pangan Indonesia pada dasarnya telah mulai tercakup pemenuhan standarisasi yang ditentukan oleh negara-negara lainnya yabg dimulai dengan penerapan sertifikasi Halal, pemenuhan standar higienis dan lain sebagainya.Tekanan dunia internasional terhadap isu halal cukup kuat, advokasi pemerintah dinilai tidak cukup kuat dapat menghadapi berbagai ancaman pihak luar menyangkut isu halal sebagai hambatan perdagangan. Ancaman dapat berupa pengaduan pada lembaga-lembaga perdagangan dunia seperti WTO dan lain-lain. Oleh sebab itu pemerintah perlu meningkatkan kemampuan Jaminan Produk Halal. Jika tidak dilakukan maka kondisi ini akan menyebabkan melemahnya tingkat kompetisi Indonesia secara Internasional, mengingat negara lain lebihmengakomodir kepentingan bisnis Internasional dalam menjalankan standar sertifikasi halalnya (Dwi Purnomo dalam Fatwa Majelis Ulama Indonesia (MUI) dalam Persepektif Hukum dan Perundang-Undangan, 2012, h. 337).

Penerapan sertifikasi Halal berdasarkan Undang-Undang Nonor 33 Tahun 2014 tentang Jaminan Halal belum sepenuhnya efektif, walaupun ketentuan tersebut harus ditempatkan sebagai ketentuan puncak dari ketentuan sebelumnya, yang dimulai dari peraturan yang terendah.

Keberadaan Undang-Undang Nomor 33 Tahun 2014 tentang Jaminan Halal masih membutuhkan waktu mengingat ketentuan tersebut mengamanatkan sejumlah peraturan pelaksanannnya harus terbentuk dalam rentang waktu dua, sampai dengan lima tahunmendatang, yang berarti secara efektif akan mulai berlaku tahun 2019. Penundaan beberapa peraturan pelaksananya tidak sampai menunda pelaksanaannya mengingat keseluruhan peraturan pelaksananya harus terwujud pada tahun 2019. Implementasi akan diharapkan lebih efektif jika dilakukan oleh negara/pemerintah, yang mana kepentingan konsumen jauh lebih luas dan lebih besar akan terlindungi (Abdurrahman Konoras, 2017, h. 100).

Hal lain yang diatur dalam Undang-Undang Nomor 33 Tahun 2014 tentang Jaminan Halal disebutkan bahwa tugas dan fungsi MUI melalui LPPOM -MUI telah diambil alih oleh Badan Pemerintah. Badan Pemerintah yang dibentuk dan bertanggungjawab kepada 
pemerintah. Konsekwensi Badan Pemerintah Jaminan Produk Halal (BPJH) sebagai salah satu penyelenggara jaminan produk halal. Sedangkan MUI hanya menjadi mitra kerja dari BPJH, mengeluarkan Auditor Halal dan lain-lainnya.Pengambilalihan penyelenggara sertifikasi halal dengan berlakunya undang-undang tersebut konsekwensi dari kewajiban pemerintah untuk melindungi hak-hak konsumen warga negaranya. Hal ini juga dapat dipahami bahwa kehadiran dari Jaminan Produk Halal adalah upaya postifikasi hukum Islam di Indonesia yang harus dimaknai dengan prinsip-prinsip utamanya yakni mewujudkan pembawa rahmat bagi semuanya (rahmatan lilalamiin).

\section{KESIMPULAN DAN SARAN Kesimpulan}

Teori efektifisita adalah mengkaji dan menganalisis tentang keberhasilan, kegagalan dan faktor-faktor yang mempengaruhi dalam pelaksanaan dan penerapannya. Di dalam Islam adanya ayat al-Quran yang mengatur masalah makanan yang haram dan yang halal bertujuan untuk kemaslahatan umat Islam itu sendiri, sebagaimana yang tertera dalam tujuan hukum Islam ((مقاصد الشرعية). Hukum perlindungan konsumen sudah memberikan aturan tentang keharusan mencantumkan label halal, agar terjamin hak-hak konsumen dan agar terhindar makanan yang haram. Undang-Undang Jaminan Produk Halal merupakan penyempurnaan undang-undang yang sebelumnya tentang pengaturan keharusan ada pelebelan halal. Undang ini diharapkan aturan yang lebih sempurna dalam melindungi konsumen dari produk haram. Kelebihan dari undang-undang ini adalah pemerintah sebagai Badan Penjaminan produk halal.

\section{Saran}

Kepastian hukum bagi konsumen terkait dengan kehalalan suatu produk haruslah diberikan kepada masyarakat khususnya bagi umat Muslim. Bagi umat Muslim makanan bukan saja harus menyehatkan akan tetapi juga haruslah yang baik terkait dengan asal usul makanan tersebut. Kepastian hukum tersebut ada pada aturan-aturan yang dibuat oleh pemerintah yang bukan hanya sekedar aturan tanpa pelaksanaan yang tidak jelas. Pelaksanaan itulah yang menjadi penting untuk memberikan kepastian hukum dan perlindungan hukum bagi setiap konsumen yang menginginkan kehalalan suatu produk makanan. Oleh karena itu, kepastian dan perlindungan hukum bagi setiap konsumen atas halal-nya suatu produk makanan harus menjadi prioritas pemerintah apalagi dalam pelaksanaan aturan-ataurannya. 


\section{DAFTAR PUSTAKA}

Ali, Zainudin. (2011). Metode Penelitian Hukum. Jakarta: Sinar Grafika.

Haekal, Muhammad Husein. (1984). Sejarah Hidup Muhammad. Jakarta: Tintamas.

Hamdani, Ikhwan. (2003). Sistem Pasar, Pengawasan Ekonomi (Hisbah) dalam Persepektif Ekonomi Islam. Jakarta: Nur Insani.

Junaidi, Wawan. (2006). Rekonsepsi Al-Istihalah dan Implikasinya Terhadap Hala-Haram Bahan Pangan Dengan Pendekatan Ilmu Kimia. Jakarta: Badan Litbang dan Diklat Departemen Agama RI.

Jusmaliani. (2008). Bisnis Berbasis Syari'ah. Jakarta: Bumi Aksara.

Konoras, Abdurrahman. (2017). Jaminan Produk Halal Di Indonesia Perspektif Hukum Perlindungan Konsumen. Jakarta: Rajagrafindo Persada.

Majelis Ulama Indonesia. (2012). Fatwa Majelis Ulama Indonesia (MUI) dalam Persepektif Hukum dan Perundang-Undangan. Jakarta: Badan Litbang dan Diklat Kementrian Agama Republik Indonesia.

Muhammad, Abdulkadir. (2004). Hukum dan Penelitian Hukum. PT. Citra Aditya.

Rahman, Afzalul. (2000). Muhammad Sebagai Seorang Pedagang. Jakarta: Swarna Bhumi.

Shabiri, Abul Futuh. (2017). Sukses Bisnis Berkat Wasiat Nabi. Jakarta: Pustaka Al-Kausar.

Sidik, H. Salim., \& Nurbani, Erlies Septiana. (2017). Penerapam Teori Hukum Pada Penelitian Tesis dan Disertasi. Jakarta: Rajagrafindo Persada.

Undang-Undang Nomor 7 Tahun 1996.

Undang-Undang Nomor 18 Tahun 2012 tentang Pangan.

Undang-Undang Nomor 33 Tahun 2014 tentang Jaminan Produk Halal.

Undang-Undang Nomor 8 Tahun 1999 tentang Perlindungan Konsumen.

Uways, Abdul Halim. (1998). Fikih Statis-Dinamis (terjemahan Zarkasyi Chumaidy, dari AlFiqh al-Islamiy Bayn at-Taqawwur wa as-Sabat). Bandung: Pustaka Hidayah.

Zulham. (2013). Hukum Perlindungan Konsumen. Jakarta: Pranadamedia Group. 